\title{
Building a culture that values learning outcomes as an integral part of effective program development - one faculty's example
}

\author{
Watson E. ${ }^{2}$, Ivey, M. ${ }^{1}$, Mohamed Y. ${ }^{1}$, Musilek P. ${ }^{1}$, Raboud D. ${ }^{1}$, Rajendran A. ${ }^{1}$, Carey J.P. ${ }^{1}$ \\ ${ }^{1}$ University of Alberta, Faculty of Engineering, Edmonton, Alberta. \\ ${ }^{2}$ University of Alberta, Centre for Teaching and Learning \& Faculty of Education, Edmonton, \\ Alberta. \\ Stream: Teaching Practice \\ Rank of modes: 1. Podium talk, 2. lightning talk session
}

\begin{abstract}
In 2016 and 2017, the Faculty of Engineering made significant efforts to review the state of all programs, and our course learning outcomes and redevelop them as necessary. This review was driven by new Canadian Engineering Accreditation Board (CEAB) requirements to report course learning outcomes as part of the Course Information Sheets. This paper looks at the work done in collaboration with the University's Center for Teaching and Learning $(C T L)$ in undertaking this initiative.

Generally speaking, the experiences gained through this process were that learning outcomes benefit the instructors, students, and program alignment; regular workshops and one-on-one interactions improved the culture around learning outcomes amongst faculty members; having up-to-date learning outcomes must be a continuing process; learning outcomes are invaluable in ensuring continuity and consistency in course offerings; and, pedagogical/teaching service units are valuable partners in propagating pedagogical knowledge.
\end{abstract}

Keyword: Learning outcomes, Culture change, Program development, Collaborative work, Centre for Teaching and Learning, Bloom's Taxonomy.

\section{INTRODUCTION}

It has become increasingly common for Faculties of Engineering to use learning outcomes as a form of quality assurance $[1,2]$. This is not a surprising measure of quality since clear, observable, and measureable learning outcomes are integral to the success of any Engineering course [3]. In the spring of 2016, in preparation for our upcoming accreditation review, the Faculty of Engineering at the University of Alberta called upon all teaching faculty to submit learning outcomes for their courses. After reviewing hundreds of learning outcomes over 9 undergraduate programs, it had become clear to administration that instructors needed some help in both writing and teaching with learning outcomes. A large number of those learning outcomes initially received from instructors were written simply as a list of the major subjects and topics students would encounter, or as statements of general ideas to be undertaken in the course. Most instructors neglected to include statements describing what students should be able to do upon completion of the course. Since the CEAB has specific guidelines on what a learning outcome should entail, it was important instructors be educated on writing learning outcomes for engineering.

This importance prompted the Faculty of Engineering to reach out to the University of Alberta Centre for Teaching and Learning (CTL). After conversations with the CTL, it was decided that workshops on writing learning outcomes might be an effective way to reach a majority of instructors. In collaboration with an Educational Developer familiar with Engineering Education a series of workshops were offered in early 2017.

\section{METHODS}

Clear, observable, and measureable learning outcomes are integral to the success of a course [3]. Learning outcomes are critical to ensure that instructors are aware of what they should be teaching in their classes as part of a program's curriculum. They also inform students of what they should expect to learn in each of their classes and how each course fits within their program. Further, they allow instructors to focus their required course assessments.

Educational change in Engineering does not simply come from the top-down direction; it requires leadership and collaboration from all involved parties [4,5]. In addition, Prince et al [6] indicate that educational change, particularly in engineering, requires varying the types of approaches used for delivering information, along with increasing the frequency at which information is delivered. This in effect broadens the audience and consequently further spreads the message of changes being encouraged. To assist this message propagation and foster a culture of appropriate learning outcome use, an Educational Developer with familiarity in engineering education was recruited and formal workshops were developed and offered to instructors of the Faculty of Engineering as well 
as those offering Engineering courses through other faculties.

\subsection{The Introduction of Learning Outcomes}

One of the first steps in the introduction of learning outcomes to the Faculty was the delivery of several workshops designed to engage instructors in discussions about learning outcomes. It was decided that the workshops would showcase both how to write learning outcomes as well as the reasons instructors (and students) would benefit from well written learning outcomes. Learning outcomes are a vital tool in course planning [7], since they provide direction on the skills and knowledge students should be able to use by the end of the course. This is particularly important when designing course assessments; as described by Wiggins and McTighe (2005) [8], an instructor should begin by identifying their desired results (learning outcomes) and design their assessments based on these anticipated outcomes. Simply put, learning outcomes were introduced as statements of "what students should be able to do" with the information they were learning. These statements can provide both instructors and students a better understanding of the intended learning destination [9]. In addition, clearly defining learning outcomes within the context of the overall program curriculum can help to ensure continuity and consistency in course offerings from semester to semester or as course instructors change. The introduction of, and focus on, the reasons instructors and students would benefit from well written learning outcomes was one aspect of the workshop that was very well received.

When delivering the workshops, terminology found in the CEAB questionnaire and supporting documents was used to ensure that a consistent, common understanding was achieved across the faculty. The workshops focused on the pedagogical significance of learning outcomes and writing specific, measureable, and clear outcomes using Bloom's taxonomy [1]. Other faculty concerns regarding learning outcomes, such as the total number to be included in a course, were also addressed. Tips on writing effective learning outcomes and the inclusion of contextualized examples were generally seen as being very useful in providing guidance as part of the learning outcome review process.

After developing a better understanding of why one should include learning outcomes in their course (beyond the fact that they were required for CEAB accreditation), the workshop turned toward the practice of crafting useful learning outcomes. An effective learning outcome, according to the CTL [10], included three aspects: (1) it defined what students would be able to do upon completion of the course, (2) it was written in specific, behavioural terms, and (3) it provided an indication of what would be assessed and how it would be assessed. The key factor to any learning outcome was the use of a measureable verb, since this informs assessment (measurement), while identifying a specific behavioural method of achievement, and showing what a student needs to achieve in order to be successful. As is common in higher education, Bloom's taxonomy of knowledge, per Anderson \& Krathwohl (2001) [11], was used to showcase those verbs which represented the various levels of cognitive, psychomotor, and affective skills students may learn in courses. Instructors were shown the influence a verb can have on assessment as well as on a student's understanding of the depth to which they must understand a concept. For example, if an instructor were to ask students to "justify" their solution this required a much higher level of understanding, and open form of assessment, than if a student were asked to "solve" a problem. The workshop allowed instructors to discuss the use of learning outcomes and measureable verbs in their courses and culminated in them writing a learning outcome using the strategies described.

\subsection{Personalized engagement}

Further to workshops, the educational developer was available on-site in the Faculty of Engineering one afternoon per week for a several months to work with Associate Chairs (Undergraduate) and instructors. This allowed instructors the opportunity for one-on-one support and feedback when developing learning outcomes within their specific area of expertise. In doing so, the information presented during the workshops was reinforced and made more tangible and accessible to instructors.

\section{RESULTS}

The engagement of the professoriate in the workshops was quite good, reaching nearly half of the Faculty of Engineering in the first set of offerings. To continue to increase reach, additional workshops will be offered on an ongoing basis. Attendance by instructors from faculties outside of Engineering was lower, but those who attended were eager to develop their learning outcomes and consistently accessed the Educational Developer for guidance.

Subsequent meetings between Associate Chairs and/or educational developer with instructors led to course learning outcomes that included and correctly used many elements of Bloom's taxonomy while providing guidance on areas for student assessment and assessment tools. The newly developed learning outcomes showed significant improvement in their specificity, measurability, and clarity from those submitted by instructors prior to the introduction of educational change efforts.

It should also be recognized that the learning outcomes developed during this exercise are not set in stone, and are 
expected to be further refined and adapted to suit changes in the course, program and the engineering profession.

\section{EDUCATIONAL CHANGE}

To fully integrate learning outcomes across the Faculty of Engineering, it was important that a cultural shift toward outcomes-based education - where a students going through a program is expects to achieve certain goals by graduation - be initiated using the principals of educational change. Educational change is not an event, but a process [5,12]. Recognizing that change would not happen overnight, the Faculty of Engineering began implementing various aspects which would drive the change toward outcomes-based education.

Educational change in engineering requires a variety of approaches in delivering new information to best reach and incorporate all involved parties [6]. This multifaceted approach is particularly true of those changes requiring a shift in mindset or culture, such as the movement toward outcomes-based education. The cultural shift amongst this Faculty of Engineering began with the introduction and use of learning outcomes terminology in Faculty discussions. Instructors and administrators were introduced to the terminology through emails, reports, and in meetings. As the terminology permeated throughout the Faculty, the change-driving team decided to further expand upon these ideas with workshops aimed at explaining the purpose of learning outcomes and their use. In these workshops, instructors explored the idea of outcomes-based instruction and the benefits it could provide to both instructors and students, while providing an opportunity for instructors to apply these concepts in the context of their own courses. As previously discussed, these workshops were supported by inviting an Educational Developer to take up residence within the engineering buildings on campus once a week, providing an informal space for instructors to talk about learning outcomes and their courses. The team hoped that by introducing learning outcomes as being beneficial to instructors and students, and by providing informal collaboration space, that the idea of a "top down" directive could be avoided since educational change in Engineering has been shown to be most effective with leadership and collaboration from all involved parties [4]. The multipronged and collaborative approach gave space for the educational change process to occur with instructors in an informed and supported environment.

Within this multifaceted delivery, the driving team behind the change attempted to create tension amidst instructor's pedagogical philosophies. Tension can be a driving factor for educational and cultural change in engineering education [13]. Not surprisingly, after the term "learning outcomes" was introduced, many Faculty members questioned why they should include these as part of their teaching. To these worries, the educational developer often posed questions for instructors' reflection; by encountering questions around assessment strategies, course mapping, and intended student-goals, instructors were able to modify their current instruction to fit an outcomes-approach. They also started on the road to being part of the culture of outcomes-based education. As one example, when an instructor questioned the purpose behind learning outcomes, the educational developer would ask why students would take that instructor's course. The response to this question, after some reflection, often consisted of some knowledge or skills that students would be able to do when they left the course; the instructor had just not been asked to frame their thinking this way before. The educational developer was able to collaborate with the instructor to reframe their thinking by posing a tensioncreating question. This challenge to reflect was used as a catalyst to the very personal process of educational change [5]. Using tension as a driving factor, combined with the varied methods of information delivery, the team was able to encourage educational change amongst instructors towards a culture of effective learning-outcome use.

\section{CONCLUSION}

In response to updated CEAB requirements for accreditation, the Faculty of Engineering at the University of Alberta has made significant strides in reviewing and redeveloping course learning outcomes in all nine programs in the Faculty. By collaborating with the University's Center for Teaching and Learning, custom workshops were developed and delivered to faculty members, alongside one-on-one working sessions with Associate Chairs and instructors. In so doing, the faculty embarked on a path to change the culture of the Faculty in support of outcomes-based education. Such change is expected to take time and require continuous reinforcement to achieve; however, we have already seen very promising signs. The educational developer was able to inform and teach instructors about the value of proper pedagogical planning, something that was challenging for Faculty leaders alone.

In the future, the Faculty and programs will need to quantitatively investigate the differences between the sets of learning outcomes and qualitatively investigate instructor's growth in the writing of, and teaching with, learning outcomes to determine the impact of our efforts.

\section{References}

[1] Tamer El-Maaddawy and Christopher Deneen, Outcomes-based assessment and learning: Trialing change in a post-graduate civil engineering course. Journal of University Teaching \& Learning Practice, vol. 14, no. 1, pp. 17, 2017.

[2] Svein Michelsen, Agnete Vabø, Hanne Kvilhaugsvik, and Endre Kvam, "Higher Education Learning Outcomes and Their Ambiguous Relationship to 
Disciplines and Professions”, European Journal of Education, vol. 52, no. 1, pp. 56-67, 2017.

[3] Lawrence Meda and Arthur J. Swart, “Analysing learning outcomes in an Electrical Engineering curriculum using illustrative verbs derived from Bloom's Taxonomy”, European Journal of Engineering Education, 2017

Available online as of February 13, 2018, at: http://www.tandfonline.com/doi/full/10.1080/0304379 7.2017.1378169

[4] Aida Guerra and Ron Ulseth. "Perspectives on Engineering Curriculum Change”, in $P B L$ in Engineering Education, Aida Guerra, Ron Ulset, Annette Kolmos (eds) SensePublishers, Rotterdam, 2017

[5] Michael Fullan. The New Meaning of Educational Change. New York, NY: Teachers College Press, 2016 (5th ed.), 352 pp.

[6] Michael Prince, Maura Borrego, Charles Henderson, Stephanie Cutler and Jeff Froyd, "Use of research based instructional strategies in core chemical engineering courses", Chemical Engineering Education, vol. 47, pp. 27 - 37, 2013.

[7] Fink, L. D. Creating significant learning experience: An integrated approach to designing college courses, revised and updated. San Francisco, CA: Jossey-Bass, 2013, 352 pp.

[8] Grant P. Wiggins and Jay McTighe, J. Understanding by design. Association for Supervision \& Curriculum Development. Alexandria, Virginia, 2005.

Available online as of February 13, 2018 at: http://www.ascd.org/ASCD/pdf/siteASCD/publication s/UbD_WhitePaper0312.pdf
[9] Daniel Denecke, Julia Kent, and Maureen T McCarthy. Articulating learning outcomes in doctoral education. Washington, DC: Council of Graduate Schools, 2017

Available online as of February 13, 2018 at: http://cgsnet.org/ckfinder/userfiles/files/ArticulatingL earningOutcomesinDoctoralEducationWeb.pdf

[10] Janice Miller-Young, A guide to learning outcomes at the University of Alberta. 2017,

Available as of February 13, 2018 at: https://www.ualberta.ca/centre-for-teaching-andlearning/services/learning-outcomes

[11] Lorin W. Anderson, David R. Krathwohl Peter W. Airasian, Kathleen A. Cruikshank, Richard E. Mayer, Paul R. Pintrich, James Raths, Merlin C. Wittrock (Eds.) A Taxonomy for Learning, Teaching, and Assessing: A Revision of Bloom's Taxonomy of Educational Objectives. Boston, MA: Pearson Education Group, 2001, 336pp.

[12] Gene E Hall and Shirley M. Hord. Implementing change: Patterns, principles, and potholes. New Jersey, USA: Pearson Education, Inc., 2015, 384 pp.

[14] Kelly Cross, Tiago Forin, Amit Jain, Lisa D. McNair, Mirana Miletic, Mani Mina, Elsa Villa and Ella L. Ingram. "Panel: Influencing culture and curriculum via revolution". Paper presented at IEEE Frontiers in Education Conference, Indianapolis, IN, 2017, 8pp.

Available as of February 13, 2018 at: https://www.computer.org/csdl/proceedings/fie/2017/ 5920/00/08190627.pdf 